\title{
The Huguenots of South Africa in history and religious identity
}

\begin{abstract}
The first aim of this article is to give an overview of some of the opinions that were expressed about the Huguenots of South Africa in history shortly before and after 1988 - the tercentenary year of their coming to South Africa. In this regard the aim of the article is also to analyse and evaluate some new historical information that was brought forward since 1988. The second aim of the article is to make a contribution to the efforts that were undertaken to establish the religious identity and heritage of the Huguenots that came to South Africa. The word "religious" is used in both the sense of their narrower church identity as well as their broader identity in life; in this regard one can also speak of their spirituality.
\end{abstract}

On April 131688 the first group of French Refugees, that came to the Cape of Good Hope as part of an official colonisation scheme of the Netherlands through the Dutch East Indian Company (DEIC), set foot on land from the ship the at Saldanha Bay, about $70 \mathrm{~km}$ north of Table Bay. The Voorschoten was part of the so called autumnal fleet which sailed from the Netherlands at the turn of the year. Sailing with the Voorschoten were six other ships with French refugees on board: the Borssenburg, Oosterland, De Schelde, Berg China, Zuid-Beveland and Wapen van Alkmaar. On Sunday 25 April 1688 the Oosterland, with Huguenots on board, was the first ship of the fleet to sail into Table Bay although the Voorschoten arrived much earlier but in Saldanha Bay (Coertzen 1976:150-154).

A few months after their arrival Van der Stel writes to the Chamber of Middelburg about the huge task to help the colonists prepare the land to plant wheat, vines and other fruit. He writes that the land that they have to till has probably never been touched or cultivated since the beginning of creation and first had to be cleared of all kinds of brush. It will take two to three years before it can start to yield any kind of harvest. A very dismal outlook indeed. Most of the refugees arrived at the Cape with empty hands. In his letter Van der Stel states that all the material they needed for agriculture and to build their homesteads were much more expensive here than in the fatherland - a fact which necessitates them to be in debt with the Company (State Archives Cape Town: C502, Outgoing Documents (1688-1690): 15 April 1689 to Chamber of Middelburg).

Unlike some of the French refugees that fled to other countries like Germany, the Netherlands and England those that came to the Cape, with the exception of a few, were very poor people.

It is also very important to always distinguish between the Huguenots that came to South Africa on their own initiative and those who came to the southern tip of Africa as part of the official colonisation scheme of the Dutch East Indian Company. The larger part of Huguenots that came to South Africa officially as colonists came more or less during the years 1688-1689. Already in 1691 Van der Stel wrote to the Chamber of Middelburgh asking them to rather not 
send any more refugees of the kind of the Huguenots to the Cape. His reasons were that the French were ill behaved; they did not have much knowledge of farming and were only a burden to both the Company and the diaconate because of their poverty. The last ship with a significant number of Huguenots on board was the Driebergen that left Holland on 25 May 1698 (State Archives Cape Town: C 423, Incoming Documents (1697-1699): 7 May 1698). With this ship we can say that the official colonisation scheme of the DEIC to bring Huguenots to South Africa was over. In fact already after 1688 we find that the Lords XVII never again officially discusses the matter of French refugees as colonists for the Cape.

From the facts and figures available to us it is not possible to say exactly how many French refugees arrived at the Cape. According to the lists of Huguenots who arrived at the Cape there were 9 up until 1687. They came on their own and not as part of the official colonisation scheme. The official colonisation scheme started in 1688. In that year the number of Huguenots at the Cape increased by 138 and in 1689 by a further 20. This means that by the end of 1689 a total of 158 Huguenots arrived at the Cape under the official colonisation policy of the Company. This figure agrees with that given in Van der Stel's Letter of June 12, 1690 to the Lords XVII in which he states that there were altogether 150 odd refugees. During 1690 another 9 Huguenots arrived and in 1691 another 11 . This means that by the end of 1691 there were 178 French refugees at the Cape who had been sent out by the DEIC. According to the list from Batavia 171 Frenchmen were given assistance. This figure is reasonably close to the one of 178 mentioned above. After 1691 we know from available documentation of another 10 Huguenots that came to the Cape - in 1696 the Vosmaer with 5 Huguenots on board, arrived in Table Bay. Originally it was a party of ten but en route five died. (State Archives Cape Town: C 595: Day Journal 1696: 17 October 1696). In 1698 the Driebergen with five Huguenots on board left Holland for the Cape (State Archives Cape Town: C423 Incoming Documentation (1697-1699): 7 May 1698). This brings the total number of Huguenots at the Cape that came out as part of the official scheme of the DEIC to 193. Nevertheless we find that in spite of the termination of the official colonisation scheme French Refugees still kept coming to the Cape of Good Hope. By 1702 the total number had grown to 229; by 1726 there were 278 Frenchmen at the Cape. By 1729 another refugee arrived and this gives a grand total of 279 by 1729 of whom 193 came as part of the official colonisation scheme of the DEIC.

By 1692 the total European population at the Cape were about 856 freemen. If we work on a total Huguenot population of about 193 by 1692 it means that by that year they formed 22,54\% of the total European population. By 1702 the number of Huguenots had grown to about 229 out of a European population of 1368, which means that by 1702 the Huguenots formed $16.73 \%$ of the total European population. These are significant percentages of Huguenots, enough for them to have had considerable influence on the southern tip of Africa during the early years of their settlement.

In his sermon at the bicentennial anniversary of the Cape of Good Hope the Rev Abraham Faure pointed out that in the 'establishment of the Christian Church in South Africa' God provided 'about eighty families (more or less 150 persons) who fled the bloody persecution in France - to find asylum at the Cape. God continues to use their offspring if one considers the fact that 16 of the 26 ministers of Cape descent, serving the Dutch Reformed Church in 1852 can trace their background to a French Refugee (Faure 1852:15,52).

During the course of time the religious influence of the original refugees and their descendants were felt throughout the whole of South Africa and even further north into Africa. In this regard we can think of the missionary travels of someone like Prof Johannes du Plessis, a Huguenot descendant and professor at the Theological Seminary in Stellenbosch. Du Plessis was not the only theologian of Huguenot descent at the Seminary. Up until 2009 we find the names 
of at least 13 Huguenot descendents among the staff members of the Theological Seminary in Stellenbosch, later the Faculty of Theology of the Stellenbosch University, from a total staff of 56 between 1859 and 2009: JI Marais (23/8/1827-27/8/1919; J du Plessis 25/7/1868-16/2/1935; DG Malan 23/3/1880-3/3/1937, DW de Villiers 30/11/1919-15/5/2002; JL de Villiers 8/3/19222010; J du Preez 16/8/1927-; DA du Toit 8/1/1942-2/4/2010; PF Theron 4/8/1942-7/7/2010; BA du Toit 22/11/1937-; AEJ Mouton 21/1/1952-; J H Cilliers 10/8/1954-; I A Nell 28/4/1961- and AL Cloete 12/6/1971-. It is a question whether the names of D Lategan 23/2/1880-27/12/1953 and JPJ Olivier 31/11945-25/3/1998 cannot also be added to this list. These academics of course had and still have a very far-reaching influence not only in the Dutch Reformed Church but also in other reformed churches and across the whole of Africa and further abroad (Coertzen 2009:161-165). The names of Huguenot descendants can also be found amongst the ministers and members of all Christian denominations in South Africa.

The results of a survey published in the Sunday Times Magazine on October 4, 1981 showed that amongst the 36 largest families of European descent in South Africa there are nine Huguenot surnames, namely Nel, Du Plessis, Coetzee, Fourie, Du Toit, Le Roux, Viljoen, Marais and Du Preez. In the first four volumes of the South African Biographical Dictionary there are articles on 25 people with the surname De Villiers, 17 on Du Toits, 12 on Malans, 9 on Jouberts, and 8 on Viljoens. The names of Huguenot descendants are found amongst the leaders and achievers in every area of life in South Africa - religion, social, economic cultural life, research and development, agriculture, sports and politics, as military leaders and as heads of state; as poets, writers, artists and composers. Alas, the names of Huguenots descendants can also be found among those who took wrong turns in life. Name any area of life and the names of Huguenot descendants will be found there, too many to mention. One must also remember that the Huguenot descendants are not only those people with Huguenot names. There are many South Africans who do not have French surnames but who nevertheless have a large percentage of Huguenot blood in their veins.

The Huguenots of South Africa originally came to South Africa as refugees and colonists to help provide for a Dutch supply station and trading post at the Cape. They settled largely in the district of Drakenstein and within four decades the French language disappeared and they completely became South Africans. They identified with their fellow Dutchmen in their new context and religiously they found a home in the Dutch Reformed Church, a church that was religiously and spiritually from the same root as the Reformed Churches in France and the Walloon Church in the Netherlands.

In 1967 Beryl Anne Verner from the School of Librarianship at the University of Cape Town compiled a bibliography Huguenots in South Africa. The bibliography has 171 entries under various headings ${ }^{1}$

1 (A) History - (1a) General South African history, (1b).General Huguenot History, (1c) Travel Journals - (2) Huguenots in South Africa (2a) Books, (2b) Periodicals, (2c) Articles and pamphlets, (2d) Special issues of periodicals. ;

(B) The Contribution of the Huguenots to South African Life: (1) General, (2) The French Language in

South Africa, (3) Architecture, (4) Church History, (5) The wine industry.

(C) The Huguenots in South African Literature: (1) Poetry, (2) Drama, (3) Fiction

(D) Huguenot Monuments and Memorial celebrations

(E) Genealogies and names: (1) General, (2) Genealogies of individual families, (3) Heraldry

(F) Index to authors.

(G) Index to serials. (Verner,1967,i) 
Verner refers to the fact that there is indeed not very much 'official documentation' about the Huguenots and that it can be said with reasonable certainty that the existing documents have been thoroughly researched and are reflected in the published works (Verner 1967:iii). Verner also refers to 'very little literature' by and about the Huguenots, which are available in 1967.

Between 1925 and 1929 Prof Franken published various articles on Huguenot writings in French. In 1987 these articles were published in the Yearbook of the South African Archives, no 41. There are also collections of texts by C G Botha and CC Spoelstra, which were found in The Hague and in Amsterdam. In $1988 \mathrm{MJH}$ du Plessis translated all the French texts that were available and made them available. This work of great value indeed opens new avenues on the Huguenots that wait to be explored. (Du Plessis 1988:Xerox copy)

In an article from 1988 'The French Refugees in South Africa and the Historiography of the nineteenth century' prof E Brown draws valuable conclusions in an attempt to understand the identity of the Huguenots in SA history. He points out that the contribution of the French Refugees was only seriously considered after the English took over the Cape at the beginning of the nineteenth century. Their influence were idealised within the context of distinctive situations, a historical awareness, and a historical development - be it to justify the British take over, to theologically and ecclesiastically accommodate the new situation or on the other hand to resist the English management and policy in favour of closer links with the Netherlands. Or be it to explain the emergence of the Afrikaners as a people with their language Afrikaans. Brown is also of opinion that it was only during the nineteenth century that the French Refugees became the French Huguenots or the Huguenots of South Africa (Brown 1988:93-95). The name can of course already be found in documents from the sixteenth century. It does remain a question why the name Huguenot was not used in South Africa until the nineteenth century.

In 2008 an article by R Britz 'The French Refugees in $20^{\text {th }}$ century South African historiography' takes the historiography on the Huguenots further. In this he exposes valuable material. His conclusion is that one is struck by the positive evaluation and acceptance that the Huguenots received in SA historiography. He then continues, 'The collection and study of primary sources however did not prevent contextualised presumptions, suppositions, images and unreliable socio-historical and religious theories. The Calvinism /Calvinistic/Calvin paradigm especially needs meticulous investigation of primary sources, since it is also connected to the question of Calvin's direct influence in South Africa, a subject that has been presented in the past in terms of popular misleading assumptions, based on (questionable) secondary sources' (Britz 2008:21) It is certainly a legitimate issue that Britz places on the agenda and thorough research of primary sources has to be done as well as reformulations or closer formulations if necessary. Britz himself does not offer an answer except to point out that in the past the historiography of the Huguenots have been used to support all kinds of ideas of the day - from support of the British occupation to Afrikaner nationalism.

Britz is not the only one who questions the so-called 'Calvinistic' influence of the Huguenots in South Africa. Victor D'Assonville, Hermann Gilliomee and Richard Elphick also question their 'Calvinistic' influence. D'Assonville claims that 'The line from Calvin via France to the Cape of Good Hope is not as clear-cut or as straight as it has been stated in recent publications' (D'Assonville 2008:68). For Gilliomee and Elphick it has not been shown ' ... what aspects of Calvinist doctrine permeated what regions and classes at the Cape, in what forms, and in what areas. It has not even been shown that Calvinism was influential at all' (Elphick \&Gilliomee 1979:363). Gilliomee and Elphick do not 'assert that Calvinist doctrine had no influence on social stratification at the Cape, only that the argument for such influence has yet to be made.' They also point out 'that the Cape was notoriously lacking in schools, churches and vigorous intellectual life' in those early years. (Elphick \& Gilliomee, 1979,364). 
Philippe Denis in his article 'The Cape Huguenots and Their Legacy in Apartheid South Africa' closes his article with the following words: 'South Africa has now entered another era. The Afrikaner people, who developed the Huguenot myth as a way of strengthening their identity, have lost their leading position in the government of the country. This new situation creates the conditions for a more critical appraisal of the role of the Huguenots in South African history' (Denis 2003:303). Apparently Denis sees the claims about the Huguenots as a 'myth' which Afrikaners invented as a way to strengthen their identity and now that they have lost their leading position in government it opens the way for a more critical appraisal of the role of the Huguenots in history.

One of the latest and also a much-acclaimed work on the history of South Africa is the book The New History of South Africa. (Tafelberg 2007, Eds. Hermann Gilliomee and Bernard Mbenga). The book recognises the contribution of the Huguenots to the history of South Africa. It mentions that the Huguenots were refugees due to religious persecution. It was the expressed policy at the Cape that they must assimilate with the Dutch and learn the Dutch language and ethos. They helped to stabilise the free citizenry at the Cape and it was their experience of religious persecution that prepared them and made them determined to overcome the obstacles with which they were faced in a new country. Their descendants in South Africa occupied leadership roles in South African society out of proportion to original number of immigrants that came to the Cape. Another contribution was the fact that with the Huguenots coming as families, more women came into the Cape society which eventually lead to much more stable marital relationships in the Cape society. Between 1720 and 1790 four times more vineyards were planted at the Cape, the wheat harvest trebled and the netto worth of estates also trebled. By 1730 a new class of 'hereboere', rich landowners, came into existence at the Cape. Measured in terms of land, vineyards, wheat harvests and livestock ownership, they formed about $10-20 \%$ of the rural citizen population. Of the most well-known of these families more than $50 \%$ were Huguenot descendants (Gilliomee \& Mbenga 2007:60,66).

The forgoing statements and viewpoints pose challenges to church historians and must be taken note of. They all need serious and honest attention and continued research has to be done to really understand and open the history of the Huguenots of South Africa. This article tries to meet some of the challenges but surely much more research is necessary.

Historians must of course also be careful not to pose their questions just out of their own time and context, such as, for instance, that at the moment it is not popular at all to claim any heritage of Calvin in South Africa. Does this kind of questioning do justice to the historical documents, contexts and circumstances of the sixteenth, seventeenth and eighteenth centuries? Indeed a critical appraisal is necessary but also an honest and objective search to really understand the sixteenth and seventeenth centuries both in Europe and in South Africa, in all its facets of religion, economy, social life, ecclesiastical life and spirituality as well as political relations and policies - indeed to really understand the history of the Huguenots of South Africa and its real meaning.

A remarkable thing about the Huguenots in the history of South Africa is that during the past decades all kinds of new information have been brought forward which sheds further light on the identity and heritage of the Huguenots of South Africa. I refer here the rerhyming of the Psalms by Pierre Simond and his introduction to the rerhyming, which was discovered round about 1996. It is the rhyming of the Psalms of David by the French Huguenot minister at the Cape Pierre Simond under the title Les Veilles Afriquaines ou Les Pseaumes de David mis en vers 
François together with a Preface. We know that this work was published in the first years of the eighteenth century but for centuries no trace of it could be found until 1996, when a copy was found in the State Library of St Petersburg. This work together with its preface has opened a whole new set of information on the Huguenots of South Africa.

Between 1699 and 1701 Pierre Simond, did his rerhyming of the Psalms of David during the African nights on his farm Bethlehem in the Berg River valley and the joining valleys, where the Huguenots, the members of his congregation, were settled. Through this work Pierre Simond was responsible for the very first piece of religious and literary work written in South Africa and eventually published in Amsterdam (Vigne 1998:3; Pierre Simond's Psalms, 2). He started this work in 1699 in the midst of the congregation of Drakenstein (Vigne 1998:3, Pierre Simond's Psalms, 2) The work contains Simond's metrical versions of Psalms 1 to $51,74,79,103,130,137$ and 143 as well as the versification of the Ten Commandments and the Nunc Dimittis or the song of Simeon.

In I 701 Simond left the Cape to go and present his work to the Walloon Synod in the Netherlands. The French speaking European churches had been looking for a new version of the Psalms because the old version had become very difficult because of the changes in the French language. The churches in Switzerland had accepted the version created by Conrard and De la Bastide and requested all other French-speaking churches to accept it as well. The Walloon churches in the Netherlands however refused to accept the new Swiss version and decided to work on an own completely new version. (Bibliotheque Wallonne, stukke nr 60, Articles resolus au Synode de Rotterdam, le neuviemme Septembre et jours suivans de I, annee dix sept ans). It is this decision that brought Simond to return to the Netherlands with his version. However when he arrived in the Netherlands, Synod had already decided to abandon the whole project. Simond then had his version published under the title of Les Veilleés Afriquaines ou les Pseaumes de David mis en vers Francais. It was published in 1704 by Comelle de Hoogenhuisen of the Eglantiersgragt in Amsterdam and thus it became the first work not only of literature (Vigne 1998:3). But also of Reformed theology written in South Africa and to be published (Pierre Simond's French Psalms, 2). For nearly three hundred years we knew that this publication existed but had no copy of it. In 1996 it came to light through Mr Gertjan Buitink of Belgium that there was a copy of the book in the State Library of St Petersburg in Russia. Through the kind co-operation of the Library of the Stellenbosch University and the State Library of St Petersburg a photocopy was sent to South Africa in 1997. In 2000 the original copy was studied in St Petersburg. This helped to determine why a copy ended up in St Petersburg. It was namely one of the books in the library of the Saluzki brothers, both bishops in Warschau that went to St Petersburg by the end of the eighteenth century. Half of this library went back to Warschau between 1921 and 1933. These books were destroyed during the Second World War. Fortunately for South Africa and the world Les Veilles Afircaines remained in St Petersburg (see Coertzen 2001). In 2002 a facsimile was published in Stellenbosch, a few kilometres from the place where it was originally written in 1699 . This certainly was a remarkable contribution from the Huguenots of South Africa to reformed theology and liturgy and also to the literary history of South Africa and it is a good thing that after nearly three hundred years this remarkable publication has come home. It also needs to be mentioned that in 1708 a rerhyming of all the Psalms by Pierre Simond was published in Lille by Balthazar le Franq under the title Les Pseaumes de David Mis en vers François. It is a pity that this publication does not also bear the title Les Veilles Afriquaines, most probably because the full rerhyming was done in Europe after a positive response to Les Veilles.

In the mean time it has also come to light that there is a reference to the Les Veilles Afriquaines in a book by Jennet from 1706 Les Pseaumes de David en vers. Nouvelle version, dans laquelle on a retenu les expressions de Marot \& de Beze autant que l'usage modeme a pü le permettre. 


\section{THE RELIGIOUS IDENTITY OF THE HUGUENOTS}

The Huguenots made a large contribution to the growth of South Africa in many fields. This article wants to concentrate on their religious and spiritual heritage. Within all the fields of their influence their religious heritage was very important. In a sense it is not easy to determine and describe exactly what this heritage consisted of. Les Veilles Afriquaines and the Preface to it, which came to light during the past years, however does help us to grasp and understand this heritage in a better way. Like the Dutch who had arrived before them, the Huguenots were also bearers of the reformed religion and along with that also of the influence of John Calvin. Calvin had a very strong bond with the French Reformed Churches - he states it explicitly in the foreword to his Christian Institutes that he especially wrote that work for his fellow French countrymen among which there were many who hungered and thirsted for Christ (Calvyn 1559:89). In the preface to his commentary on Daniel he states unequivocally that it would be a sin to forget the people of the country (France) to which he belongs (Calvin, Letter to the French People 18 August 1561). In other countries the influence of Calvin was spread by students, correspondence as well as through his writings. As a born Frenchman he gave his best abilities to France. He showed his concern for his fellow countrymen throughout his life. In the sixteenth century Calvin gave the French churches a stable organisation; he trained their ministers and drew up a confession of faith for them. He was a valued adviser to them. It stands to reason that the context and circumstances in France and the rest of Europe changed much since the death of Calvin in 1564 and the revocation of the Edict of Nantes in 1685 and the coming of the Huguenots to SA in 1688. Much also changed in the spirituality and the way of thinking form the time of the Reformation in the sixteenth century to the Enlightenment and the call for a Second Reformation in the seventeenth and eighteenth centuries.

As seen above it is often a point of discussion whether there is any real tangible influence of Calvin on South Africa through the Huguenots. There are historians who explicitly question the fact that the Huguenots were carriers of the influence of John Calvin to South Africa. There are however indications that the Huguenots, or at least some of them laid a bond between South Africa and John Calvin. When this is said it must be remembered that most of the Huguenots that came to South Africa were not highly educated people who did a lot of theological reflection and wrote long treaties on their worldview and spirituality. They were mostly farmers and artisans, and good ones at that, fathers, mothers, children, members of their local congregation. The question to answer is, what was the motivation of their life and to what kind of teaching were they exposed to, what were the ideas that influenced them, what was the ethos that they practised in their everyday life and work? To try and determine the religious identity and heritage of the Huguenots of South Africa attention is going to be given to three aspects: the theology of Pierre Simond, the spirituality of some of the Huguenots and the position and character of catechetical teaching in the congregation of Drakenstein up until about 1723.

With regard to the theological views of Pierre Simond the following is new and important information after 1988. Between 1699 and 1701 Pierre Simond, the Huguenot minister did his rerhyming of the Psalms of David. It was published in Amsterdam in 1704 as Les Veilles Afriquaines ou les Pseaumes de David Mis en Verse François. During the African nights on his farm Bethlehem in the Berg River Valley and the joining valleys, where the Huguenots, the members of his congregation, were settled, he did this work.

Psalm 8:4 he rendered as follows:

"Que'est ce de l'homme, alors dis-je en moi-même:

Qu'il en souvienne, ô Majesté suprême?

Qu'est du fils de l'homme, ô Dieux des Cieux

Que de son bien tu te montres soigneux? 
In 1706 one Jennet in the work Les Pseaumes de David en Vers Nouvelle Version. Dans laquelle on a retenu les expressions de Marot \& de Beze que l'usage moderne a pûle permettre writes the following on Psalm 8:4 (It is found in the original version) 'O God what is man that you think of him, and the Son of man that you visit him. I have consulted various translations in French verse, none mention the Son of man. This is astonishing because the Son of man is depicted in the rest of the Cantique as having great power and the words used by the prophet are so magnificent that one cannot do otherwise than to attribute it to Jesus Christ, eternal God' ('Il se trouve dans le Pseaume 8.v.4. II y a dans l'Original ô Dieu, qu est-c-que de l'homme que tu te souviennes de lui, $\&$ du Fils de l'homme que tu le visites. J'ai consulté plusieurs traductions en vers François, aucune ne fait mention du Fils de l'homme. Cela est assez etonnant, car ce Fils d l'homme est depeint dans la fuite du Cantique ayant un si grand pouvoir, \& les termes, employés par le prophéte, sont si magnifiques, qu'on ne peut les atrribuer qu'à Jesus Christ, Dieu béni éternellement.'). He then continues to ask why the Son of man is not mentioned in a book which we use every day. He himself might have fallen into this trap if he did not have a discussion with a very wise and very well known theologian who wanted the fourth verse to keep this passage. Then he writes the following: 'The only version which expresses this place faithfully has the title Les Veilles Afriquaines, it was published two years ago. It is hoped that the author of this book also has the same good knowledge of French and the rules of poetry as well as the Hebrew and the force of that language; his version would prevail over all the ones that we have.' ('Ia Seule Version qui a pour titre Les Veilles Afriqaine, \& qui parut ily a a deux ans, exprime fidlement cet endroit: II seroit à souhaiter que l'Auteur de ce Livre eút aussi bien sçeu le François \& les régles de la Poësiee que IHebreu \& la force de cette langue; sa Version l'emporteroit sur toutes celles que nous avons.') (Jennet 1706:13).

According to Jennet, Pierre Simond succeeded in his rhyming to convey this very important phrase. The important question is do we find any of the theological ideas of John Calvin in this translation of Simond. Even if we cannot say that here is a literal rendering of the theology of John Calvin we can say with certainty that in his rerhyming of Psalm 8:4 in the way he did it, Pierre Simond is in line with the theology of John Calvin as it is found in his translation and exposition of Psalm 8:3-6 (Calvin 1855:99-107). That this translation by Simond, in keeping the phrase 'The Son of man' conveys the ideas of Calvin is confirmed even more strongly in Calvin's commentary on the Book of Daniel where he unequivocally states on the Phrase 'the Son of Man', 'without doubt this is to be understood of Christ' (Calvin 1853:40). In this John Calvin in Geneva during the sixteenth century and Pierre Simond in 1699 at the southern tip of Africa, in the Drakenstein Valley, concur. And this must have also been the kind of theological ideas to which the members of the Drakenstein congregation were exposed to, ideas, which must have influenced their way of thinking and the spirituality, which they exercised - their exercitia pietatis.

With regard to the theology of Pierre Simond it must also be remembered that the Huguenots that came to the Cape were most probably members of the Walloon Church in the Netherlands. We know for a fact that Pierre Simond was a minister of the Walloon congregation of Zierickzee before he came to the Cape. Of this Church it was said that their synodical structure that was formed by 30 to 40 particular churches, and this was used to protect the identity of a pure, reformed church, which desired not to deviate from pure doctrine in any point. Justly Colvius could say of these churches in 1705 'Although they recommend love in all things, they show, up to this point in time, disposition towards error and God has, up to now, granted them the grace that under them there is no discord in doctrine and there are no parties which distinguish themselves by name or method' (Van't Spijker 1990:71). Pierre Simond also did his theological training at the academy of Die, which was known as a reformed institution modelled on the academy of Genève. 
We also find expression of the spirituality of those early Huguenots in some of their writings that were kept. Gideon le Grand, a medic (chirurgyn), starts his diary for the year 1710 with the words: 'With the break of day start your day by blessing the holy name of the Eternal God. In the evening when your labour is done praise Him again and so pass the year' - these words are written at the beginning of his diary for 1710, a diary in which he records his life as a heal master in his community and writes about his healing practice, his art of healing and the and the medicaments that he used. But the introduction to all of this is the confession of his faith in God and how he thinks that one should live in the presence of God. In his diary of words, which convey a strong spirituality, rooted in God (Le Grange Journal 1710, in Franken 1978:153-154). Another example of the spirituality we find in the notes of Maria Jeanne du Pré; notes which she made at the birth of each of her children as well as those of her sister Jacomina starting on 7 August 1698 and ending on 27 August 1718. For each of her own children she writes a biblical characterisation, which corresponds with the name of the child, followed by a prayer for the particular child. For the children of her sister she writes a prayer for the blessing of the child. She concludes all these little poems for each child with the following: 'O Vader aller weezen bewaarder aller vromen./ Laat uwen segenshand tot deze kindren komen./ Brengt haar na volle jaaren in uwe genaderijk./ Dat zij u Eeuwig looven in de hemel al gelijk" (O, Father of all children, protector of the pious. Let your hand of blessing come to these children. After a full life bring them into your kingdom of grace. That they may all praise you eternally in heaven) (Copia in Franken 1978:167-168).

In both cases, that of Gideon Le Grand as well as that of Maria Jeanne du Pré it is a deep faith in God that finds expression, not only in a worship service but also in the happenings of everyday life. Their religious belief about how life should be lived everyday and the expression of their belief in God and their prayer for the future of a child at its birth. It is not the words of learned theologians but the words of the faith of ordinary people who heard the Word of God proclaimed to them and then went on to witness to it and proclaimed it themselves in their everyday life. This was the kind of spirituality of the Huguenots, which is not to say that all of them were in every way holy people on earth and that every one had this kind of spiritual expression; for that there is too much evidence to the contrary. But if we compare these expressions of spirituality, with the viewpoints of Pierre Simond and with the witness in official documents about the spiritual state in the congregation of Drakenstein we can most certainly conclude that a spiritual life and witness were not mere words amongst many of the Huguenots.

The Huguenot congregation as a whole also made its contribution to the spirituality of the Church at the Cape. In 1729 (K.K.A. G3 111 Resolutions of the Church Council of Drakenstein, 6 November 1729) the congregation was said to be to be seen as the most diligent in the country, an opinion which was confirmed on the 31st of January 1731 in a letter from the church council of Cape Town to the Classis of Amsterdam (Letter form the Church Council of Cape Town to the Classis of Amsterdam, 31 January 1731. In Spoelstra, Bouwstoffen Deel I, I35-136). In this they undoubtedly not only confirmed their own identity but also contributed to the growth of religious zeal and godliness within the Dutch Reformed Church as a whole.

This kind of spirituality, which finds its deepest roots in the reformation of the sixteenth century, was part of the heritage that they bequeathed to their new fatherland.

Another document that gives us insight to the kind of teaching to which the Huguenots were exposed to in those first years of their settlement are the catechetical books that was used in the congregation of Drakenstein - the so called Huguenot congregation. In this regard there was the catechism written and used by Paul Roux, Belijdenis des Geloofs (Confession of Faith). The exact date of this work is unsure. We do however have a handwritten copy of the work done by H C von Wieding in 1743. Paul Roux himself lived form 1665-1723 (Coertzen 1988:168). From 
this we can at least deduce that the catechism must have been written before 1723 . This is the oldest written question book, or catechism that has originated at the Cape. Dr V D'Assonville subjected the book to close scrutiny. He points out that the theological roots of Roux's catechism clearly goes back to the Dutch theologian Johannes d'Outrein (1662-1722) and from him there is also a link to the German theologian FA Lampe (1683-1729). Lampe published notes on the German translation of D'Outrein's commentary of the Heidelberg Catechism. These notes were translated into Dutch. D'Assonville is of opinion that due to historical reasons Roux was much more dependent on d'Outrein for his own catechism than he was on Lampe. Lampe's work Erste Wahrheitsmilch für Säuglinge am Alter und Verstand was published in 1717 while the first edition of d'Outrein's Korte Schets was already published in 1687. This book of d'Outrein was widespread as can be seen from the fact that it was translated into German, French, English, Malaysian and Portuguese. It is very interesting that we read in the minutes of the church council of Drakenstein under the date of 18 March 1718 that the Lords XVII had decided to send 100 'sketse', d'Outrein's Korte Schets and 100 Oostrums - a commentary on the Heidelberg Catechism - as well as 50 Bibles to the Cape. These books could be on order (K.K.A.G3 1/1: Minutes of the Church Council of Drakenstein, 18 March 1718). By 1721 there is once more a need for these books and the congregation is asked to save money to buy the books from a bookseller (K.K.A.G3 1/1: Besluite Kerkraad Drakenstein, 2 Februarie 1721). From this information as well as from Roux's dependence on d'Outrein it is fair to state that at least the content of the Heidelberg Catechism must have been known in the Drakenstein congregation during the years that Paul Roux was there as teacher. While there are significant parallels between Roux's Catechism and d'Outrein's work there are also significant differences. D'Assonville comes to the conclusion that the catechetic education in Drakenstein during the first half of the eighteenth century indicates an influence of the Second Reformation (Nadere Reformasie) - 'i.e. a form of reformed orthodoxy' (D'Assonville 2008:67). He is also of opinion that it must be taken into account that the Voetius- and Coccejus traditions are united in d'Outrein which according to him means that the reformed orthodoxy of the seventeenth century '-- had started to be infiltrated by the ideas of the Enlightenment' (D'Assonville 2008:67). This leads him to the statement 'The line from Calvin via France to the Cape of Good Hope is not as clear-cut or as straight as it has been stated in recent publications' (D'Assonville 2008:68).

Perhaps another short note from the Preface of Les Veilles Afriquaines is appropriate at this point. In his Introduction to the rerhyming of the Psalms Simond gives us an interesting piece of information regarding the type of catechesis, which he used with his own children. He writes that on Pentecost Sunday 1699 he gave his children, as he was used to do every Sunday, a Psalm as task for the rest of the week. On that day the children themselves asked for Psalm 50. It is then that they discover that the new Psalm (the rhyming of Conrart and De La Bastide) have five verses and not four like the old rhyming of Clement Marot, in which Marot co-operated with Calvin. Simond then compares both the new version of Conrart and De la Bastide and the old version of Marot with the Scripture text and according to him he concludes that both versions are left wanting. This prompts him then to start his own rerhyming of the Psalms (Simond, Les Veilles Afriquaines, Introduction, 3 in sequence (unnumbered page). Apart from this very interesting information we also get a little insight into what the religious learning material for children in the congregation of Drakenstein must have been towards the end of the seventeenth century - at least for the children of the minister.

5. CONCLUSION

We should not over estimate the influence of the initial group of Huguenots on South Africa. 
They have often in the past been credited with consequences that occurred only 100 or 150 years after their arrival at the Cape. They have also often in the past been and even in the present time are idealised, as though each one of them was a high-minded representative of French Calvinism or carriers of a certain sought after French lifestyle. The fact is that they were refugees, ordinary and mostly very poor and mostly not highly educated people who were often difficult to please and not easy to satisfy. They had their vices and sins, quarrelled amongst themselves and with their fellow people. There were those who had extra-marital affairs, who were accused of being dishonest and there were those who had to be reprimanded by the church council. The fact is that no kind of eugenic aims were applied in the selection of either the Dutch or French colonists for the Cape, so that not only the best people emigrated to the Cape (Besselaar 1934:292-297; Du Toit 1895:48-49).

It has been questioned in recent times whether they brought any Calvinistic influence to South Africa and evidence for such a Calvinistic influence is being asked. There is even talk of a Huguenot myth created by Afrikaners as a way of strengthening the Afrikaner identity. As far as the theology of the spiritual leader of the Huguenot congregation, Pierre Simond is concerned, there is a definitive concurrence between his theological views and that of John Calvin - and for this there is documentary evidence - this is no myth created by Afrikaners!

There is also evidence of a reformed devotion and piety from their ranks and of a deep faith commitment. This was seen in the writings of Gideon le Grand and Jeanne Marie du Prés, ordinary people inspired in their every day life by their faith in God. For this too there is documentary evidence, as shown.

With regard to the catechetical teaching in the congregation of Drakenstein we have seen what the method of Pierre Simond himself was - he gave Psalm verses to his children as their task for the week. We have also seen from the documents that the books of d'Outrein and Van Oostrum that was ordered and used in the congregation and that at least the Heidelberg Catechism must have played an important part in the teaching of the children. Through his analysis and evaluation of the Catechism used by Paul Roux, D'Assonville has pointed out influence of the Second Reformation as well as that of the Enlightenment. This conclusion must however also be seen against the background of the role that the Heidelberg Catechism apparently also played.

D'Assonville is right when he states that there is no direct and straight line from Calvin to South Africa. Much happened between 1564 and 1688 and 1723 (the date of Paul Roux's death). Nevertheless through the Huguenots of South Africa a line of connection can be established between Calvin and South Africa and this line, even if at times very vague, can be seen in the theology and work of Pierre Simond, the spirituality of ordinary people and the catechetical work in the congregation of Drakenstein. And all of this is part of the religious identity that those first Huguenots have left to South Africa. It is also very sure that even from them up to our own time there is no direct and straight line.

\section{BIBLIOGRAPHY}

D’Assonville, Victor E., 2008, Early theology at the Cape of Good Hope - A German-Dutch connection? Some notes on the theology of a French Refugee in the early $18^{\text {th }}$ century. In: Andreas Flick and Walter Schulz (Hg), 2008, From Sweden to South Africa. Proceedings of the International Huguenot Conference in Emden 2006. (pp 51-74), Verlag der Deutschen Hugenotten-Gesellschaft e.V. Bad Karlshafen.

Besselaar, G,1934, IntellectueelLeven in Zuid-Afrika. In: Antirevolutionaire Staatkunde, jrg 8, 1934.

Bibliotheque Wallonne stukke $\mathrm{nr} 60$. Articles resolus au Synode de Rotterdam, le neuviemme Septembre etjours suivans de l'annee dix-sept ans.

Brochure: Hugenote - Gedenkmuseum, Franschhoek.

Brown, E, 1990, The French Refugees in South Africa and the Historiography of the $19^{\text {th }}$ Century. In: AD 
Pont (editor),1990, Calvin - France - South Africa. Papers read at the third South African Congress on Calvin research, Stellenbosch, $26-29$ July 1988. Kital: Pretoria.

Britz, D, 2008, The French Refugees in $20^{\text {th }}$ century South African historiography. In: Andreas Flick und

Walter Schulz (HG.), Von Schweden bis Südafrika. Vorträge der Internationalen Hugenotten-Konferenz in Emden 2006. (pp9-33). Verlag der Deutschen Hugenotten-Gesellschaft e.V., Bad Karlshafen.

Burger, W J ,1 940, Die Invloed van die Franse Hugenote op Suid-Afrika. In: Careers, vol X, nr I.

Calvyn, JI 1559, Institusie van die Christelike Godsdiens. Translated by H.W. Simpson. Calvyn Jubileum Boekefonds (CJBF), Potchefstroom, 1984.

Calvin, 18 August 1561 , Letter to the French People. In: Schwarz, R, Joannis Calvins Lebenswerk in seinem Bnefen III, p 1133).

Calvin, John, 1855, Commentary on the Book of Psalms. Translated from the original Latin and collated with the authors French version by the rev James Anderson. Printed for the Calvin Transaltion Society, Edinburgh.

Calvin, John, 1853, Commentaries on the Book of the Prophet Daniel. Vol 1 \& 2, Translated by Thomas Myers. Edinburgh.

Cape Church Archives: G 3,111: Minutes of Resolutions taken by the Church Council of Drakenstein 1715 1730.

Cape Church Archives: A.G3 1/1: Minutes of Resolutions taken by the Church Council of Drakenstein 18 March 1718

Cape Curch Archives: A.G3 1/1: Minutes of Resolutions taken by the Church Council of Drakenstein 2 February 1721

Coertzen, P, 1976. Die Franse Hugenote in Suid-Afrika. 'n Kerkhistoriese Studie. Proefskrif ingelewer vir die graad Doktor in die Teologie aan die Universiteit van Stellenbosch.

Coertzen, P, 1988, The Huguenots of South Africa 1688-1988. Tafelberg, Kaapstad.

Coertzen, P, 2001 , Les Veilles Afriqualnes - Afrika Nagstudies. Die Herdigting van die Psalms in Frans aan die Kaap van Goeie Hoop in 1699. In: Studiae Histonae Ecclesiasticae, Julie 2001.

Coertzen, P, 2002, The Huguenots: Origins, Settlements and Influence. The Story of a Refugee People. In: Bulletin 39, 2002. Proceedings of the 3rd International Huguenot Conference, Stellenbosch 2002. Huguenot Foundation of South Africa, P 0 Box 293, Franschhoek 7690, email: huqenoot@new.co.za, Bulletin 39, 2002. Proceedings of the 3rd International Huguenot Conference, Stellenbosch 2002.

Coertzen, P (ed) 2009, Teologie Stellenbosch 150+ Die verhaal van teologiese opleiding op Stellenbosch die mense en die geboue. Wellington: Bybel-Media.

Denis, Phillip, 2003, The Cape Huguenots and Their Legacy in Apartheid South Africa. (In Bertrand Van Ruymbeke and Randy J Sparks, 2003, Memory and Identity. The Huguenots in France and the Atlantic Diaspora. University of South Carolina Press. Columbia.

De Villiers, G D B, sa. Het Sticht Simondium. 'n Skoolinsteiling en Gedenksuil 1852-1956. Pro Ecilesia Drukkerij, Stellenbosch.

Du Plessis, M J H, 1988, Franse Hugenotegeskrifte aan die Kaap. Xerox Kopie.

Du Toit, S J, 1895, Die geskiedenis van ons land, in die taal van ons volk (2e druk). D F du Toit, Paarl.

Eene gedachtenis van het Tweehonderd-jarige Hugenoten Feest in Zuid-Afrika door de Hugenoten-School Wellington.

Elphick, Richard \& Gilliomee, Hermann (Eds), 1979, The shaping of South African Society, 1652 - 1820. Cape Town: Longman.

Faure, A, 1852. Redevoering bij het tweede Eeuw Feest ter herinnering aan de Vestiging der Christelijke Kerk, in Zuid-Afrika. Gehouden in de Groote Kerk, in de Kaapstad Dinsdag den 6 April 1852. Uitgegeven op eenparig verzoek en voor rekening der Gezamenlijke lede van den Eerwaarden Kerkeraad der Gereformeerde Kerk, Kaapstad. Kaapstad: Van de Sandt de Villiers \& Tier.

Franken, J L M, 1978, Die Hugenote aan die Kaap. Argiefjaarboek vir Suid-Afrikaanse Geskiedenis, een -enveertigste Jaargang. Die Staatsdrukker, Pretoria.

Gilliomee, H \& Mbenga, B, 2007, A New History of South Africa. Tafelberg: Cape Town

Jennet, 1706. Les Pseaumes de David en vers. Nouvelle version, dans laquelle on a retenu les expressions de Marot \& de Beze autant que I'usage modeme a pü le permettre. Utrecht, Jean Visch.

Malan, F S , I 940, Die Herdenking van die koms van die Hugenote. Herdruk uit die offisiële Jaarboek, no 21 1940. 
Pierre Simond's French Psalms. Personalia Series nr 3 . Huguenot Memorial Museum, Franschhoek,1999 Resolusies van die Politieke Raad, 1651-1669. Suid-Afrikaanse Argiefstukke, Kaapstad, 1957.

Roux, Paulus, 1743, Belijdenis des Geloofs. Cape Church Archive. Copy made from the original document by H C von Wieding, 18 May 1743.

Simond, Pierre 1704, Les Veilles Afriquaines ou Les Pseaumes de David mis en vers Francais . A Amsterdam pour le Auteur ches Comelle Hoogenhuisen, sur Leglantiers-gragt I 704.

Spoelstra, C, 1906, Bouwstoffen voor de Geschiedenis der NederduitscheGereformeerde Kerken in ZuidAfrika Deel I en II (Brieven van de Kaapsche Kerken aan de Classis Amsterdam 1655 - 1804). HollandschAfnkaansche Uitgewersmaatschappij, Amsterdam.

State Archives Cape Town: (C502, Outgoing Documents Stukke (1688 - 1690): 15 April 1689, to Middelburg)

State Archives Cape Town: C 595: Day Journal 1696: 17 October 1696

State Archives Cape Town: C 423, Incoming Documents (1697-1699): 7 May 1698)

Sunday Times Magazine, 4 October, 1981.

Van't Spijker, 1990, The Walloon Churches in the Netherlands during the Seventeenth Century. Their character, structure, preaching and influence. In: Pont, ADR, (ed) 1990, Calvin - France - South Africa. Papers read at the third South African Congress on Calvin research. Stellenbosch 26-29 July 1988. Kital: Pretoria.

Verner, Beryl Anne, 1967, Huguenots in South Africa. A Bibliography. University of Cape Town. School of Librarianship. Cape Town.

Vigne, R, 1998, South Africa's First Published Work of Literature and its Author, Pierre Simond. In: South Africa Historical Journal, 39 (Nov 1998).

P Coertzen

Stellenbosch

November 2005/ October 2010/January-February 2011 